Original Article

http://dx.doi.org/10.1590/0104-07072014000600013

\title{
FEEDING OF CHILDREN EXPOSED TO THE HUMAN IMMUNODEFICIENCY VIRUS AT BIRTH
}

\author{
Julyana Gomes Freitas ${ }^{1}$, Gilmara Holanda da Cunha², Larissa de Araújo Lemos³, Léa Maria Moura Barroso", \\ Marli Teresinha Gimeniz Galvão ${ }^{5}$
}

${ }^{1}$ Ph.D. in Nursing. Assistant Professor. Nursing School, Universidade de Fortaleza (UNIFOR). Fortaleza, Ceará, Brazil. E-mail:
julyanapitt@yahoo.com.br
${ }^{2}$ Ph.D. in Pharmacology. Assistant Professor. Nursing School, Universidade Federal do Ceará (UFC). Fortaleza, Ceará, Brazil.
E-mail: gilmaraholandaufc@yahoo.com.br
${ }^{3}$ M.Sc. in Nursing. Nurse of the Emergency Care Unity of Ceará State. Fortaleza, Ceará, Brazil. E-mail: lariss_araujo@hotmail.com
${ }^{4}$ Ph.D. in Nursing. Assistant Professor. Nursing School, UNIFOR. Fortaleza, Ceará, Brazil. E-mail: leammbarroso@gmail.com
${ }^{5}$ Ph.D. in Tropical Diseases. Assistant Professor. Nursing School, UFC. Fortaleza, Ceará, Brazil. E-mail: marligalvao@gmail.com

\begin{abstract}
The aim was to characterize feeding aspects of children born exposed to the Human Immunodeficiency Virus. Crosssectional study was developed at a referral hospital for infectious diseases in Fortaleza-Ceará, Brazil, between January and June 2010. The sample consisted of 62 mothers who provided information on 64 children born exposed to the virus. In the nursing consultation, the Assessment Scale of Care Skills for Children Exposed to Human Immunodeficiency Virus at Birth and forms for sociodemographic and dietary characterization were used. It was found that $57.8 \%$ of children had inappropriate intake of milk, $55.0 \%$ had inappropriate complementary feeding, $87.0 \%$ of mothers had a high capacity to offer milk powder and, in relation to complementary feeding, the ability ranged from moderate $(45.7 \%)$ to high $(48.5 \%)$. Thirteen nursing diagnoses showing feeding problems and deficits in care that require nursing interventions appropriate to the social context of each patient were identified.
\end{abstract}

DESCRIPTORS: Acquired immunodeficiency syndrome. Child. Feeding. Nursing diagnosis.

\section{ALIMENTAÇÃO DE CRIANÇAS NASCIDAS EXPOSTAS AO VÍRUS DA IMUNODEFICIÊNCIA HUMANA}

RESUMO: Objetivou-se caracterizar aspectos da alimentação de crianças nascidas expostas ao Vírus da Imunodeficiência Humana. Estudo transversal, realizado em hospital de referência para doenças infecciosas em Fortaleza-Ceará, entre janeiro e junho de 2010. A amostra foi de 62 mães que forneceram informações sobre 64 crianças nascidas expostas ao vírus. Na consulta de enfermagem utilizou-se a Escala de Avaliação da Capacidade para Cuidar de Crianças Expostas ao Vírus da Imunodeficiência Humana e formulários de caracterização sociodemográfica e alimentar. Constatou-se que 57,8\% das crianças possuíam ingesta inadequada de leite, 55,0\% apresentaram alimentação complementar inadequada, $87,0 \%$ das mães possuíam alta capacidade para oferta do leite em pó, e em relação à alimentação complementar, a capacidade variou entre moderada $(45,7 \%)$ e alta $(48,5 \%)$. Foram identificados 13 diagnósticos de enfermagem que constataram problemas alimentares e déficits de cuidado que exigem intervenções de enfermagem adequadas ao contexto social de cada paciente.

DESCRITORES: Síndrome de imunodeficiência adquirida. Criança. Alimentação. Diagnóstico de enfermagem.

\section{ALIMENTACIÓN DE NIÑOS EXPUESTOS AL VÍRUS DE LA INMUNODEFICIENCIA HUMANA}

\begin{abstract}
RESUMEN: El objetivo fue caracterizar aspectos de la alimentación de niños nacidos expuestos al Virus de Inmunodeficiencia Humana. Estudio transversal realizado en un hospital de referencia para enfermedades infecciosas en Fortaleza-Ceará, entre enero y junio de 2010. La muestra fue de 62 madres que proporcionaron información sobre 64 niños nacidos expuestos al virus. En la consulta de enfermería fue utilizada la Escala de Evaluación de Capacidad del Cuidar de Niños Expuestos al Virus de Inmunodeficiencia Humana, y un formulario de caracterización sociodemográfica y alimentaria. Se encontró que $57,8 \%$ de los niños tenían ingesta inadecuada de leche, 55,0\% tenía alimentación complementaria inadecuada, 87,0\% de las madres tenía alta capacidad de suministro de leche en polvo, y en relación con la alimentación complementaria, la capacidad varió de moderado (45,7\%) a alta (48,5\%). Fueron identificados 13 diagnósticos de enfermería que mostraron problemas de alimentación y déficit de atención que requieren intervenciones de enfermería apropiadas para el contexto social de cada paciente.
\end{abstract}

DESCRIPTORES: Síndrome de inmunodeficiencia adquirida. Niño. Alimentación. Diagnóstico de enfermería. 


\section{INTRODUCTION}

The increase in the number of women of childbearing age infected with Human Immunodeficiency Virus (HIV) has led to the birth of children exposed to the virus and Vertical Transmission (VT) has been the primary route of HIV infection in this population. ${ }^{1}$ In Brazil, the replacement of breastfeeding by artificial milk formula and other dietary according to age as well as zidovudine (AZT) syrup are recommended during the first six weeks of life..$^{2-3}$ These strategies ensure protection to the baby's life and reduce the possibilities of infection by HIV through VT. ${ }^{4}$

The World Health Organization (WHO) guidance on the feeding of children born to HIV/ AIDS-infected women is to discontinue breastfeeding and to use breastmilk substitutes when they are available, affordable, safe and sustainable. Otherwise, the WHO recommends exclusive breastfeeding for the first six months of life in order to reduce the morbidity and mortality of these children. ${ }^{5}$ Therefore, caregivers should have wide access to guidance on artificial nutrition indicated to newborns exposed to HIV, and health professionals should keep themselves informed about these recommendations in order to perform appropriate guidance as well..$^{5-7}$

The feeding for children under 12 months who cannot be breastfed includes choosing the type of milk according to the social and cultural context of their mother, as well as guidance on how to get milk formula which should be free for children born to HIV-infected women, milk dilution and preparation, complementary feeding $(\mathrm{CF})$ and hygiene practices. ${ }^{7}$ However, studies have claimed that the nourishment of these children has been less than ideal and inappropriate, with the early introduction of supplementary foods and proving that mothers need information about the feeding of children born exposed to HIV. ${ }^{1,8-9}$

In Brazil, 17,539 cases of AIDS were registered in the National Disease Notification System (SINAN) from 1980 to June 2012, taking into account children in the age group under five years old. ${ }^{10}$ In Ceará state, the first case of AIDS in children was reported in 1985 and 2,107 cases had been reported in 120 (65.2\%) from a total of 184 cities of Ceará by December 2012. ${ }^{11}$

In this context, there is an urgent need for further investigations on this field of nursing care. Thus, this study aimed to characterize aspects related to feeding of children born exposed to
HIV, with emphasis on dietary profile, the ability of these mothers to prepare powdered milk and $\mathrm{CF}$, as well as the nursing diagnoses of feeding problems.

\section{METHOD}

A cross-sectional and quantitative study was developed between January and June 2010, in a public hospital, a reference institution in the care of people with HIV/ AIDS in Fortaleza, Ceará, Brazil.

The sample consisted of HIV-infected women who brought their children born exposed to the virus for health monitoring visits over the study period. It is emphasized that the mothers were the core components of the sample because they are responsible for the care of their children. There were 62 mothers who provided information regarding 64 children born exposed to HIV, since two of them had twins.

The following inclusion criteria were considered: be 18 years old or older; confirmed diagnosis of HIV infection before or during childbirth; have at least one child born exposed to HIV with up to 12 months old; be in health monitoring; be mother/primary caregiver of the child. The exclusion criteria were: cognitive deficits or mental illness that did not permit answering the survey questions.

Data collection was performed during the nursing consultation of the child and the following instruments were used: 1 . Form for sociodemographic and clinical characterization of mother/ child; 2 Form for characterization of the child's dietary profile; 3 . Assessment Scale of Care Skills for Children Exposed to HIV at Birth (EACCCHIV), developed and validated in Brazil. ${ }^{6}$ This scale assesses the health care focused on children born exposed to HIV, from birth to 12 months of age, according to five factors: factor I - ability to administer AZT syrup for children up to 42 days of life; factor II - ability to prepare and administer powdered milk for children under one year of age; factor III - ability to prepare and administer complementary feeding for children over four months of age; factor IV - ability to administer prophylaxis with trimethoprim-sulfamethoxazole for children over 42 days old for up to one year; and factor $\mathrm{V}$ - ability to ensure adherence to clinical monitoring and vaccination.

The general scale score range is $52-260$ points, distributed in three levels of ability to care: low (52-121 points), moderate (122-191 points) and 
high (192-260 points). Each factor can be evaluated separately, indicating the degree of care developed by the mother in every aspect. For the aims of the study, only factors II and III of EACCC-HIV were considered, which were composed of $17 \mathrm{e}$ 22 questions, respectively. According to levels of ability to care, the scale score ranges for factor II (low: 17-40, moderate: 41-64, high: 65-88) and for factor III (low: 22-51; moderate: 52-81, high: $82-110)$. From the nursing consultation and from the information obtained by means of forms and EACCC-HIV, nursing diagnoses were identified according to Taxonomy II of the North American Nursing Diagnosis Association (NANDA). ${ }^{12}$

STATA software version 11 was used for data analysis. The variables were described by univariate and bivariate distribution frequencies. The mean, standard deviation and median were obtained for the continuous variables. The bivariate analyses were performed to measure differences between levels of ability to care, as expressed by the factors analyzed in the EACCC-HIV and Fisher's Exact test was used for the evaluation of maternal characteristics. The significance level considered was 5\% (P£ 0.05).

The project was approved by the Research Ethics Committee of the hospital where the study was conducted, under protocol 043/2009. All participants signed a consent form.

\section{RESULTS}

The most prevalent age of mothers was between 20 and 29 years old (46.8\%), 66.1\% were in the early stages of the disease, and the predominant diagnosis time was less than one year (61.3\%). The number of childbirths was between one and three children (88.7\%). Regarding the level of education, $32.2 \%$ had less than five years of study. The majority $(85.5 \%)$ was unemployed and the predominant family income was between one and two Brazilian minimum wages $(46.8 \%)$. The Brazilian minimum wage value was $\mathrm{R} \$ 510.00$ at that time. Among children, 35 were male (54.7\%) and the ages were as follows: eight children ( $\leq$ 1 month; $12.5 \%), 16$ (2-3 months; $25.0 \%$ ), 18 (4-6 months; $28.1 \%$ ) and 22 ( $\geq 7$ months; $34.4 \%$ ). As for serology (viral RNA), one child was reactive (1.6\%); 12 were nonreactive $(18.7 \%) ; 17$ had inconclusive serology $(26.7 \%)$ and 34 had not yet performed the examination (53.0\%).

In relation to the children's dietary profile, most had not been breastfed by their mothers.
The highest percentage of mothers used milk formula Nestogênio ${ }^{\circledR}$, but 37 children $(57.8 \%$ ) had inappropriate milk intake, with irregularities regarding the milk dilution and supply frequency. Forty children were at the age to start CF, but ten children only consumed milk. These data are described in table 1.

\section{Table 1 - Dietary profile of children born exposed to HIV. Fortaleza-CE, 2010}

\begin{tabular}{|c|c|c|}
\hline Variables & $n=64$ & $\%$ \\
\hline \multicolumn{3}{|l|}{ History of breastfeeding } \\
\hline Yes & 2 & 3.0 \\
\hline No & 55 & 86.0 \\
\hline Cross-breastfeeding & 7 & 11.0 \\
\hline \multicolumn{3}{|l|}{ Milk type } \\
\hline None & 2 & 3.1 \\
\hline NAN 1® & 7 & 10.9 \\
\hline Nestogênio® & 30 & 46.9 \\
\hline Ninho ${ }^{\circledR}$ & 11 & 17.2 \\
\hline Other & 14 & 21.9 \\
\hline \multicolumn{3}{|l|}{ Consumption of milk } \\
\hline Appropriate & 27 & 42.2 \\
\hline Inappropriate & 37 & 57.8 \\
\hline \multicolumn{3}{|c|}{ Dilution of milk in the recommended proportions } \\
\hline Hypoconcentrated dilution & 7 & 11.0 \\
\hline Hyperconcentrated dilution & 16 & 25.0 \\
\hline Correct dilution & 27 & 42.2 \\
\hline Uninformed* & 14 & 21.8 \\
\hline \multicolumn{3}{|l|}{ Frequency of milk supply } \\
\hline Oversupply & 30 & 46.8 \\
\hline Reduced supply & 7 & 11.0 \\
\hline Appropriate frequency & 27 & 42.2 \\
\hline \multicolumn{3}{|l|}{ Complementary feeding $(\mathrm{n}=40)$} \\
\hline Yes & 30 & 47.0 \\
\hline No† & 10 & 15.5 \\
\hline \multicolumn{3}{|c|}{ Consumption of complementary food $(\mathrm{n}=40)$} \\
\hline Appropriate & 18 & 45.0 \\
\hline Inappropriate & 22 & 55.0 \\
\hline
\end{tabular}

* Dilution of milk not informed; 'Should be using complementary feeding, but had not yet started.

Table 2 shows the aspects related to the milk preparation. As for hygiene in the preparation of milk, it was observed that some mothers neither washed their hands before handling food $(11.3 \%)$, nor wiped the place where they prepared the milk $(9.7 \%)$. Moreover, the tissue towels used to dry the materials utilized in the preparation of milk were not always clean and dry $(32.3 \%)$ and, sometimes, baby bottles and other materials were not hygienised properly. Many mothers used to administer milk to their babies at least two hours after 
preparation; when they were away from home and carried appropriate water supply to prepare the milk with them. In some cases, the conditions of the milk storage container, expiration date of the milk $(24.0 \%)$, as well as appropriate milk storage location $(5.0 \%)$ were not observed.

Table 2 - Aspects related to the preparation of powdered milk for children born exposed to HIV. Fortaleza-CE, 2010

\begin{tabular}{|c|c|c|c|c|c|}
\hline Aspects related to powdered milk $(n=62)$ & $\begin{array}{l}\text { Never } \\
\text { n (\%) }\end{array}$ & $\begin{array}{c}\text { Rarely } \\
\text { n (\%) }\end{array}$ & $\begin{array}{c}\text { Some-times } \\
n(\%)\end{array}$ & $\begin{array}{l}\text { Often } \\
\mathrm{n}(\%)\end{array}$ & $\begin{array}{c}\text { Always } \\
\text { n (\%) }\end{array}$ \\
\hline Handwashing before preparing the milk & $7(11.3)$ & - & - & - & $55(88.7)$ \\
\hline Cleanliness where preparing the milk & $6(9.7)$ & - & - & - & $56(90.3)$ \\
\hline $\begin{array}{l}\text { Use of clean and dry cloth to dry material } \\
\text { exclusively for preparing the milk }\end{array}$ & $20(32.3)$ & - & - & - & $42(67.7)$ \\
\hline $\begin{array}{l}\text { Clean and boil the material used in the } \\
\text { milk preparation }\end{array}$ & $2(3.2)$ & $4(6.5)$ & $10(16.1)$ & $2(3.2)$ & $44(71.0)$ \\
\hline $\begin{array}{l}\text { Proper cleaning of the baby bottle, us- } \\
\text { ing appropriate brush and boiling it } \\
\text { afterwards }\end{array}$ & $4(6.5)$ & $5(8.0)$ & $8(12.9)$ & $6(9.7)$ & $39(62.9)$ \\
\hline $\begin{array}{l}\text { Use within } 2 \text { hours when preparing the } \\
\text { milk and the child does not take it } \\
\text { immediately }\end{array}$ & $2(3.2)$ & $3(5.0)$ & $7(11.2)$ & $1(1.6)$ & $49(79.0)$ \\
\hline $\begin{array}{l}\text { Carry boiled, filtered or bottled water to } \\
\text { prepare the milk when going out }\end{array}$ & $1(1.6)$ & $1(1.6)$ & $5(8.1)$ & - & $55(88.7)$ \\
\hline $\begin{array}{l}\text { Observe the milk can conditions and the } \\
\text { expiration date }\end{array}$ & $15(24.0)$ & $1(1.6)$ & $2(3.2)$ & $2(3.2)$ & $42(68.0)$ \\
\hline $\begin{array}{l}\text { Preserve the can in dry and ventilated } \\
\text { place }\end{array}$ & $3(5.0)$ & $7(11.0)$ & $3(5.0)$ & $16(26.0)$ & $33(53.0)$ \\
\hline
\end{tabular}

About hygiene habits in the preparation of $\mathrm{CF}$, most mothers did not hygienize fruits and vegetables appropriately and did not use water proper for food preparation. Sometimes, the garbage was improperly stored in open containers at home. Large proportion of mothers (53.3\%) always used to add sugar during the preparation of CF. Some children consumed coffee, canned food, fried food and soft drinks daily $(13.3 \%)$. Thirteen mothers always used baby bottle to administer milk, soups and smoothies. See table 3.

Table 3 - Aspects related to complementary feeding of the children born exposed to HIV. FortalezaCE, 2010

\begin{tabular}{|c|c|c|c|c|c|}
\hline $\begin{array}{l}\text { Aspects related to complementary feed- } \\
\text { ing }(n=30)\end{array}$ & $\begin{array}{c}\text { Never } \\
\text { n ( } \%)\end{array}$ & $\begin{array}{c}\text { Rarely } \\
\text { n ( } \%)\end{array}$ & $\begin{array}{c}\text { Some-times } \\
\text { n (\%) }\end{array}$ & $\begin{array}{l}\text { Often } \\
\text { n }(\%)\end{array}$ & $\begin{array}{c}\text { Always } \\
\text { n (\%) }\end{array}$ \\
\hline $\begin{array}{l}\text { Wash fruits and vegetables under run- } \\
\text { ning water, and sodium hypochlorite } \\
\text { or bleach for } 30 \text { minutes }\end{array}$ & $28(93.3)$ & - & - & - & $2(6.7)$ \\
\hline $\begin{array}{l}\text { Cook food for the children with boiled, } \\
\text { filtered or bottled water }\end{array}$ & $5(16.7)$ & - & - & $1(3.3)$ & $24(80.0)$ \\
\hline $\begin{array}{l}\text { Wash the baby bottle every time giving } \\
\text { food, using brush and boiling all the } \\
\text { material }\end{array}$ & $2(6.7)$ & $2(6.7)$ & $5(16.7)$ & $2(6.7)$ & $19(63.2)$ \\
\hline Clean the place where you prepare food & $1(3.3)$ & $1(3.3)$ & $3(10.0)$ & $2(6.7)$ & $23(76.7)$ \\
\hline $\begin{array}{l}\text { Let the garbage in covered wastebaskets } \\
\text { or sealed plastic bags }\end{array}$ & $11(36.7)$ & - & $1(3.3)$ & $1(3.3)$ & $17(56.7)$ \\
\hline $\begin{array}{l}\text { Let the food cooked on the stove for } \\
\text { more than } 2 \text { hours }\end{array}$ & $22(73.3)$ & $2(6.7)$ & $4(13.3)$ & $2(6.7)$ & - \\
\hline Use sugar in the diet & - & $2(6.7)$ & $9(30.0)$ & $3(10.0)$ & $16(53.3)$ \\
\hline
\end{tabular}


Feeding of children exposed to the human immunodeficiency...

\begin{tabular}{lccccc}
\hline $\begin{array}{l}\text { Consumption of coffee, canned food, } \\
\quad \text { fried food, soft drinks, snacks }\end{array}$ & $14(46.7)$ & $8(26.7)$ & $3(10.0)$ & $1(3.3)$ & $4(13.3)$ \\
$\begin{array}{l}\text { Use blender to make vegetable or fruit } \\
\quad \text { porridge }\end{array}$ & $1(3.3)$ & $1(3.3)$ & $11(36.7)$ & $3(10.0)$ & $14(46.7)$ \\
$\begin{array}{l}\text { Offer water between meals } \\
\text { Use baby bottle to give soups or smoothies }\end{array}$ & $6(20.0)$ & - & - & - & $24(80.0)$ \\
\hline
\end{tabular}

Regarding the care skills, 62 mothers responded to factor II, with higher frequency for high care skills $(87.0 \%)$, ie, most of the mothers had high ability to prepare and administer the powdered milk. For factor III, which involves the ability to prepare and administer the $\mathrm{CF}$, the highest frequency of responses were concentrated between moderate (45.7\%) and high capacity (48.5\%), thus, the care skills of most mothers ranged from moderate to high level (Table 4). There were no significant differences between the distribution of maternal variables (age, developmental stage of the disease, time of diagnosis, childbirth, education and family income) and ability to prepare and administer the powdered milk and CF.

Table 4 - Distribution of maternal variables and their ability to administer powered milk and complementary feeding. Fortaleza-CE, 2010

\begin{tabular}{|c|c|c|c|c|c|c|c|c|}
\hline \multirow{2}{*}{$\begin{array}{l}\text { Maternal } \\
\text { variables }\end{array}$} & \multicolumn{3}{|c|}{$\begin{array}{l}\text { Ability to prepare and administer } \\
\text { powered milk (factor II) }\end{array}$} & \multirow{2}{*}{$\mathbf{P}^{*}$} & \multicolumn{3}{|c|}{$\begin{array}{l}\text { Ability to prepare and administer } \\
\text { complementary feeding (factor III) }\end{array}$} & \multirow{2}{*}{$\mathbf{P}^{*}$} \\
\hline & $\begin{array}{c}\text { Low } \\
\text { n (\%) }\end{array}$ & $\begin{array}{c}\text { Moderate } \\
\text { n (\%) }\end{array}$ & $\begin{array}{l}\text { High } \\
\text { n (\%) }\end{array}$ & & $\begin{array}{c}\text { Low } \\
\text { n (\%) }\end{array}$ & $\begin{array}{c}\text { Moderate } \\
\text { n (\%) }\end{array}$ & $\begin{array}{l}\text { High } \\
\text { n (\%) }\end{array}$ & \\
\hline Age group $\dagger$ & & & & 0,195 & & & & 0,836 \\
\hline$<30$ & - & $3(42.9)$ & $32(59.3)$ & & $1(50.0)$ & $8(50.0)$ & $11(64.7)$ & \\
\hline $30-39$ & $1(100.0)$ & $3(42.9)$ & $21(38.9)$ & & $1(50.0)$ & $7(43.8)$ & $5(29.4)$ & \\
\hline $40-49$ & - & $1(14.2)$ & $1(1.8)$ & & - & $1(6.2)$ & $1(5.9)$ & \\
\hline Stage of the disease & & & & 0.791 & & & & 1.000 \\
\hline HIV & $1(100.0)$ & $4(57.1)$ & $36(66.7)$ & & $1(50.0)$ & $9(56.3)$ & $9(52.9)$ & \\
\hline Aids & - & $3(42.9)$ & $18(33.3)$ & & $1(50.0)$ & $7(43.7)$ & $8(47.1)$ & \\
\hline Time of diagnosis $†$ & & & & 0.508 & & & & 0.868 \\
\hline$\leq 1$ & - & $5(71.4)$ & $33(61.1)$ & & $1(50.0)$ & $10(62.5)$ & $8(47.1)$ & \\
\hline $2-5$ & $1(100.0)$ & $1(14.3)$ & $15(27.8)$ & & $1(50.0)$ & $5(31.3)$ & $7(41.2)$ & \\
\hline$\geq 6$ & - & $1(14.3)$ & $6(11.1)$ & & - & $1(6.2)$ & $2(11.7)$ & \\
\hline Childbirths $\ddagger$ & & & & 1.00 & & & & 0.481 \\
\hline $1-3$ & $1(100.0)$ & $6(85.7)$ & 48 (88.9) & & $2(100)$ & $13(81.3)$ & $16(94.1)$ & \\
\hline$\geq 4$ & - & $1(14.3)$ & $6(11.1)$ & & - & $3(18.7)$ & $1(5.9)$ & \\
\hline Education§ & & & & 0.063 & & & & 0.740 \\
\hline$\leq 5$ & $1(100.0)$ & $5(71.4)$ & $14(26.0)$ & & $1(50.0)$ & $6(37.5)$ & $4(23.5)$ & \\
\hline $6-9$ & - & $1(14.3)$ & $20(37.0)$ & & - & $4(25.0)$ & $7(41.2)$ & \\
\hline$\geq 10$ & - & $1(14.3)$ & $20(37.0)$ & & $1(50.0)$ & $6(37.5)$ & $6(35.3)$ & \\
\hline Family income || & & & & 0.624 & & & & 0.928 \\
\hline$<1$ & - & $2(28.6)$ & $22(40.7)$ & & $1(50.0)$ & $5(31.3)$ & $7(41.2)$ & \\
\hline $1-2$ & $1(100.0)$ & $3(42.8)$ & $25(46.3)$ & & $1(50.0)$ & $8(50.0)$ & $8(47.1)$ & \\
\hline$\geq 3$ & - & $2(28.6)$ & $7(13.0)$ & & - & $3(18.7)$ & $2(11.7)$ & \\
\hline
\end{tabular}


With the data obtained through the nursing consultation, application of forms and scale, 13 nursing diagnoses were identified, according to the Taxonomy II of NANDA, which is a clinical assessment on individual responses, family or community to actual or potential health problems and life processes. ${ }^{9}$ Table 5 shows the nursing diagnoses and their respective domains.

Tabela 5 - Nursing diagnoses related to maternal care in the feeding of children born exposed to HIV. Fortaleza-CE, 2010

\begin{tabular}{|c|c|}
\hline Nursing diagnoses & $\mathrm{n}=64$ \\
\hline \multicolumn{2}{|l|}{ Domain - Nutrition } \\
\hline $\begin{array}{l}\text { Imbalanced nutrition: less than body } \\
\text { requirements }\end{array}$ & 7 \\
\hline $\begin{array}{l}\text { Imbalanced nutrition: more than body } \\
\text { requirements }\end{array}$ & 30 \\
\hline Risk of deficient liquid volume & 6 \\
\hline \multicolumn{2}{|l|}{ Domain - Activity/rest } \\
\hline Deficit in the care of feeding & 37 \\
\hline \multicolumn{2}{|l|}{ Domain - Perception/cognition } \\
\hline Deficient knowledge & 37 \\
\hline Ineffective activity planning & 28 \\
\hline \multicolumn{2}{|l|}{ Domain - Roles in relationships } \\
\hline Breastfeeding stopped & 55 \\
\hline Caregiver role stress & 62 \\
\hline \multicolumn{2}{|l|}{ Domain - Coping/stress tolerance } \\
\hline Health behaviour prone to risk & 28 \\
\hline \multicolumn{2}{|l|}{ Domain - Security/protection } \\
\hline Risk of infection & 64 \\
\hline Risk of contamination & 28 \\
\hline \multicolumn{2}{|l|}{ Domain - Growth/development } \\
\hline Risk of developmental delay & 7 \\
\hline Risk of disproportionate growth & 7 \\
\hline
\end{tabular}

As for domain 2, related to nutrition, three diagnoses were identified: imbalanced nutrition, less than minimum body requirements, characterized by lack of food in appropriate quantity and inaccurate information because the amount of milk supply was smaller than the recommended, due to low family income; imbalanced nutrition more than body requirements was characterized by ingestion of concentrate food due to excessive intake in relation to metabolic needs, which may contribute to overweight; in some children and it was found that daily consumption of liquids was limited, leading to a risk of deficient fluid volume due to lack of knowledge of the mother about the importance of liquid to the body and to deviations affecting access to liquids, such as low socioeconomic condition and age extremes.
A deficit in self-care feeding was observed, characterized by the inability to prepare food properly for administering it to the child, due to lack of financial resources and appropriate guidance. This diagnosis relates to caregiver, because the child is not able to promote self-care by itself. Some mothers showed deficient knowledge characterized by inappropriate verbalization of the problem and bad compliance with instructions due to lack of information and lack of interest in learning.

The incompetence of mothers to dilute the milk, the fact that some children should be using the $\mathrm{CF}$, as well as inappropriate hygiene habits during food preparation were featured. Ineffective planning activity was found, characterized by lack of resources, related to lack of family support, with negative influence on food preparation and administration to the child. Another diagnosis, interrupted breastfeeding, was characterized by poor nutrition of the child in every feeding, due to contraindication of breastfeeding because of HIV infection.

Caregiver role stress was characterized by apprehension about the future, with regard to the ability of the mother to care for her child due to the disease severity and socioeconomic problems. The health behavior prone to risk was identified, characterized by the lack of prevention of health problems by the mother due to inappropriate social support, low economic conditions and inadequate understanding.

Risk of infection is a common nursing diagnosis for all children, whether by the inappropriate immunity feature of their age or because they are considered potentially infected, as some are still in the period of seroconversion. Risk of contamination was reported, considering as risk factors domestic hygiene practices and living in poverty, which increases the potential for multiple exposures to infection, lack of access to health care and poor diet. Finally, some children were at risk of developmental delay, and risk factors were poverty, infections, poor nutrition and inappropriate prenatal care. Further, disproportionate growth risk was revealed, considering as the risk factors: poverty, infection and maladaptive eating behaviors.

\section{DISCUSSION}

In order not to breastfeed their children, women with HIV should be counseled about the risk of HIV transmission through breast milk. However, in countries where sanitation conditions 
and access to water and infant milk formula are still restricted, it is indicated the use of breast milk as a way to encourage the survival of the child. ${ }^{5,13}$ In Brazil, children born exposed to HIV have a right to have free infant milk formula until at least six months of age. It is up to the health care team to explain the preparation of milk and nutritional guidelines. To facilitate the access of mothers to the milk, it is recommended that the distribution is performed at specialized services in which the child will be monitored. ${ }^{3}$

Some mothers administered milk and CF improperly regarding to amount and preparation. Admittedly, poor education and insufficient monthly income are risk factors for morbidity and mortality, especially when children are not breastfed. The financial condition is the major interfering situation in the quality of life of these women and can hinder self-care and special treatment. ${ }^{14}$ Additionally, these mothers are not oriented properly. It is emphasized that while the literature on dietary guidelines for children born exposed to HIV is restricted, there are studies and manuals that disclose guidelines and enable mothers' learning. ${ }^{7,15-16}$

In this context, the complexity of monitoring this type of demand is evident. The increasing number of women with HIV is not regarded by the health services. Therefore, these mothers do not get guidance on the use of infant milk formula and CF at the ideal time. ${ }^{17}$ The feeding recommended to children born exposed to HIV should be monitored as outpatients, otherwise it may increase the risk of diseases, such as diarrhea and malnutrition, due to lack of guidance on the preparation of food, particularly in environments deprived of drinking water or without relevant socioeconomic and cultural conditions ${ }^{18}$ Furthermore, the dilution of the artificial milk can be performed without criteria. In this view, the child whose risk of infection is higher for not being exclusively breastfed, also ends up getting an inadequate formulation of nutrients. ${ }^{14}$

In Brazil, the Ministry of Health has developed a manual that shows how to prepare food for children under 12 months who cannot be breastfed. When there is an indication for the use of infant milk formula, the milk preparation should follow the manufacturers' instructions and respect the child's age. However, powdered milk should be diluted as follows: for children 0-4 months, $5 \mathrm{~g}$ of powdered milk should be added to every $50 \mathrm{ml}$ of water; for children older than 4 months, $7.5 \mathrm{~g}$ of powdered milk should be added to every $50 \mathrm{ml}$ of water. ${ }^{7}$
The baby bottle use was prevalent in the administration of milk and CF. Studies have shown that, even though widely used, we do not recommend the use of baby bottles for offering any food because it can be a source of infection and can interfere with oral dynamics. ${ }^{17}$ Food must be offered in appropriate glassware when breastfeeding is not possible. ${ }^{8}$

Despite the problems identified in relation to the dilution and preparation of milk and CF, the mothers' ability to take care scores ranged mainly between moderate and high. In this regard, HIVinfected mothers are afraid that their children are seropositive or get sick more often. This concern lasts until the definitive diagnosis of the child, so they strive within the possibilities, to take care of them as best as possible. ${ }^{19-20}$

Regarding the assistance provided by nurses, the process of decision-making in healthcare requires critical thinking and appropriate actions to address the problems identified. In this context, the nursing diagnoses exert profound influence in determining the needs of patients, providing support for guidance and appropriate behaviour focused on existing problems. ${ }^{21}$ In this research, some nursing diagnoses were more prevalent, such as imbalanced nutrition: more than body requirements, deficient knowledge, interrupted breastfeeding, caregivers role stress and the risk of infection and contamination. Similar diagnoses have also been identified in pediatric patients from other contexts, such as a pediatric clinic of a teaching hospital ${ }^{22}$ and in hospitalization due to respiratory diseases. ${ }^{23}$

Therefore, to provide comprehensive care to human beings in various forms of health care, the nurses require the use of a methodology that allows a qualified assistance and organized actions. For this purpose, the Nursing Care System (NCA) might be adopted, an instrument that allows the identification, understanding and preparation of patient responses to health problems. ${ }^{24}$ The NCA in nursing practice, education and research is an emergent priority for the profession, as it represents a form of logical reasoning that enables an interrelationship of causes and effects of changes manifested by the patient. ${ }^{25}$ In addition, it facilitates the establishment of goals, the adoption of nursing conduct and evaluation of the assistance to these mothers who often go through deprivations in various aspects of life that can negatively interfere with the care of the child. 
The obtained nursing diagnoses showed to be relevant, as well as the nursing interventions focused on these patients, because nutritional support for children born exposed to HIV is essential for proper growth and development and prevention of malnutrition, improving quality of life in immunosuppressed patients. In most cases, these patients have cellular changes that difficult the supply and assimilation of nutrients, resulting in weight loss and deterioration of nutritional status. Malnutrition may unfavorably influence the mortality rate by decreasing tolerance to treatment and increase of the time and relapse of hospitalization. ${ }^{26}$

The WHO and the United Nations Programme on HIV/AIDS (UNAIDS) indicate that nutritional interventions are part of the programs of control and treatment of AIDS, with the nutrition being vital for health, regardless of HIV status, so that attention to diet and nutrition can improve adherence and effectiveness of antiretroviral therapy and quality of life of children infected or exposed to HIV. All HIV seropositive mothers should receive counseling and regular routine support to ensure that they are able to make appropriate decisions about child feeding, and fulfill them effectively. Studied have shown that women need at least monthly contacts with frequent support immediately after giving birth. This counseling should be continued for at least 18 months after childbirth, and preferably for 24 months.

\section{CONCLUSION}

The study highlighted the deficiencies related to the preparation and provision of food to children born exposed to HIV. As evidenced, subsidies to improve the health care of both mother and child are necessary for problem identification and expansion of therapeutic care strategies in order to minimize morbidity and mortality. An expressive group of the mothers did not have high capacity to prepare and administer the powdered milk and the $\mathrm{CF}$, which may reflect deficiency in health care because these mothers did not receive appropriate information from the professionals that assist for them.

Thus, the urgent need is clear to guide these mothers in developing skills in order to overcome the difficulties in following the guidance on feeding their children. The importance of NCA and nursing diagnoses stands out, because they can help to identify real or potential problems, which require different nursing actions, especially in health education. Therefore, nursing care is emphasized as a differential in care for this population.

Regardless of the results of this study, some limitations must be mentioned. One of them is the fact that data collection occurs in the health facility where there is no way to directly observe the preparation of food, which would be possible when only visiting the home environment. Furthermore, more research on this subject is needed, considering the increase of HIV infection in women of childbearing age and the consequent birth of children exposed to the virus. Here, the importance of the nurse's role in the development of interventions targeted to existing problems is highlighted, taking into account the social context of each patient and the resources available for health care.

\section{REFERENCES}

1. Vieira ACBC, Miranda AE, Vargas PRM, Maciel ELN. Prevalência de HIV em gestantes e transmissão vertical segundo perfil socioeconômico, Vitória, ES. Rev Saúde Pública. 2011 Ago; 45(4):644-51.

2. Ministério da Saúde (BR). Secretaria de Vigilância em Saúde, Programa Nacional de DST e Aids. Recomendações para terapia antirretroviral em crianças e adolescentes infectados pelo HIV. Brasília (DF): MS; 2009.

3. Ministério da Saúde (BR). Secretaria de Vigilância em Saúde, Programa Nacional de DST e Aids. Recomendações para profilaxia da transmissão vertical do HIV e terapia antirretroviral em gestantes. Brasília (DF): MS; 2010.

4. Silva MJM, Mendes WS, Gama MEA, Chein MBC, Veras DS. Perfil clínico-laboratorial de crianças vivendo com HIV/AIDS por transmissão vertical em uma cidade do Nordeste brasileiro. Rev Soc Bras Med Trop. 2010 Jan-Fev; 43(1):32-35.

5. World Health Organization (SW). Guidelines on HIV and infant feeding: principles and recommendations for infant feeding in the context of HIV and a summary of evidence. Geneva (SW): WHO; 2010 [acess 2012 Dez 10]. Disponível em: http:/ / www.who.int/maternal_child_adolescent/ documents/9789241599535/en/index.html

6. Barroso LMM, Freitas JG, Galvão MTG. Escala para avaliação da capacidade para cuidar de crianças expostas ao HIV. Rev Enferm UFPE [online]. 2013 [acess 2013 Mar 5]; 7(1):772-30. Disponível em: http:/ / www.revista.ufpe.br/revistaenfermagem/ index.php/revista/article/view/2944/pdf_2159

7. Ministério da Saúde (BR). Secretaria de Vigilância em Saúde, Secretaria de Atenção à Saúde. Guia prático de preparo de alimentos para crianças menores de 
12 meses que não podem ser amamentadas. Brasília (DF): MS; 2005.

8. Paim BS, Souza GC. Práticas alimentares de crianças expostas à transmissão vertical do HIV acompanhadas em quatro serviços especializados de Porto Alegre/RS. Rev HCPA. 2010 Jul-Set; 30(3):252-7.

9. Vieira M, Padilha MI, Santos EKA. Histórias de vida: mãe e filho soropositivo para o HIV. Texto Contexto Enferm. 2009 Jan-Mar; 18(1):33-40.

10. Ministério da Saúde (BR). Secretaria de Vigilância em Saúde. Departamento de DST, AIDS e Hepatites Virais. Boletim Epidemiológico - AIDS e DST. Ano IX n. 01. Até semana epidemiológica $26^{\mathrm{a}}$ - junho de 2012. Brasília (DF): MS; 2012.

11. Governo do Estado do Ceará (CE). Coordenadoria de Promoção e Proteção à Saúde, Núcleo de Epidemiologia, Secretaria de Saúde do Estado do Ceará (SESA). Informe epidemiológico aids. Fortaleza (CE): SESA; 2013.

12. NANDA International. Diagnósticos de enfermagem da NANDA: definições e classificações 2009-2011. Porto Alegre (RS): Artmed; 2010.

13. Atashili J, Kalilani L, Seksaria V, Sickbert-Bennett EE. Potential impact of infant feeding recommendations on mortality and HIV-infection in children born to HIV-infected mothers in Africa: a simulation. BMC Infect Dis. 2008; 8:66.

14. Machado MMT, Galvão MTG, Kerr-Pontes LRS, Cunha AJLA, Leite AJM, Lindsay AC, et al. Acesso e utilização de fórmula infantil e alimentos entre crianças nascidas de mulheres com HIV/AIDS. Rev Eletr Enferm [online]. 2007 [acesso 2013 Jan 12]; 9(3):699-711. Disponível em: http://www.fen.ufg. br/revista/v9/n3/v9n3a10.htm

15. Barroso LMM, GalvãoMTG, Cavalcante RM, Freitas JG. Cuidado materno aos filhos nascidos expostos ao HIV/ Aids. Rev Rene. 2009 Out-Dez; 10(4):155-64.

16. Machado MMT, Galvão MTG, Lindsay AC, Cunha AJLA, Leite AJM, Leite RD, et al. Condições sociodemográficas de crianças de zero a dois anos filhas de mães com HIV/Aids, Fortaleza, CE, Brasil. Rev Bras Saúde Matern Infant. 2010 Jul-Set; 10(3):377-82.

17. Schaurich D, Freitas HMB. The HIV/Aids vulnerability framework applied to families: a reflection. Rev Esc Enferm USP. 2011 Aug; 45(4):981-6.
18. Neto ETS, Faria CP, Barbosa ML, Oliveira AE, Zandonade E. Association between food consumption in the first months of life and socioeconomic status: a longitudinal study. Rev Nutr. 2009 Set-Out; 22(5):675-85.

19. Araújo MAL, Queiroz FPA, Melo SP, Silveira CB, Silva RM. Gestantes portadoras do HIV: enfrentamento e percepção de uma nova realidade. Cienc Cuid Saúde. 2008 Abr-Jun; 7(2):216-23.

20. Gonçalves TR, Piccinini CA. Experiência da maternidade no contexto do HIV/aids aos três meses de vida do bebê. Psic Teor Pesq. 2008 OutDez; 24(4):459-70.

21. Cunha GH, Galvão MTG. Nursing diagnoses in patients with human immunodeficiency vírus/ acquired immunodeficiency syndrome in outpatient care. Acta Paul Enferm. 2010 Jul-Ago; 23(4):526-32.

22. Nóbrega EV, Nóbrega MML, Silva KL. Diagnósticos, resultados e intervenções de enfermagem para crianças na clínica pediátrica de um hospital escola. Rev Bras Enferm. 2011 Mai-Jun; 64(3):501-10.

23. Chagas KLM, Lima LHO, Oliveira EAR, Luz GOA. Diagnósticos de enfermagem em crianças com sinais e sintomas respiratórios: um estudo descritivo. Rev Rene. 2011 Abr-Jun; 12(2):302-8.

24. Alfaro-Lefevre R. Aplicação do processo de enfermagem: promoção do cuidado colaborativo. Porto Alegre (RS): Artmed; 2010.

25. Silva MR, Bettencourt ARC, Diccini S, Belasco A, Barbosa DA. Diagnósticos de enfermagem em portadores da Síndrome da Imunodeficiência Adquirida. Rev Bras Enferm. 2009 Jan-Fev; 62(1):929.

26. Frota MA, Ramos RP, Mourão SJG, Vasconcelos VM, Martins MC, Araújo MAL. Cuidado à criança com HIV: percepção do cuidador. Acta Scientiarum. 2012 Jan-Jun; 34(1):39-45.

27. Banco Internacional para Reconstrução e Desenvolvimento (EUA). HIV/Sida, nutrição e segurança alimentar: o que podemos fazer. Uma síntese de princípios de orientação internacionais. Washington (EUA): BIRD; 2008. [acesso 2013 Jan 10]. Disponível em: http://siteresources. worldbank.org/NUTRITION/Resources / HIVAIDSNutritionFoodSecurityPortuguese.pdf

28. Galvão MTG, Cunha GH, Machado MMT. Dilemas e conflitos de ser mãe na vigência do HIV/ AIDS. Rev Bras Enferm. 2010 Maio-Jun; 63(3):371-6. 